\title{
Southernmost record of Isurus paucus Gitart Manday, 1966 (Elasmobranchii: Lamnidae) in the southeast Pacific Ocean
}

\author{
Registro más austral de Isurus paucus Gitart Manday, 1966 (Elasmobranchii: Lamnidae) \\ en el Océano Pacífico sudeste \\ Carlos Bustamante ${ }^{1}$, Francisco Concha ${ }^{2}$, Fernando Balbontín ${ }^{2}$ and Julio Lamilla ${ }^{1}$ \\ ${ }^{1}$ Laboratorio de Elasmobranquios (ELASMOLAB), Instituto de Zoología, Universidad Austral de Chile. Casilla 567, Valdivia, Chile \\ ${ }^{2}$ Facultad de Ciencias del Mar y de Recursos Naturales, Universidad de Valparaíso, Valparaíso, \\ Casilla 5080 Reñaca, Viña del Mar, Chile \\ jlamilla@uach.cl
}

\begin{abstract}
Resumen.- Se informa sobre el registro más austral del marrajo de aleta larga Isurus paucus Gitart Manday, 1966 en el Pacífico suroriental. El ejemplar correspondió a una hembra de $310 \mathrm{~cm}$ de longitud total, capturada por un pesquero artesanal frente a la costa de Valparaíso, Chile, por un pesquero artesanal cuya especie objetivo era el marrajo de aleta corta, I. oxyrinchus. Los principales caracteres taxonómicos utilizados en la identificación del marrajo de aleta larga que permitieron distinguirlo de la otra especie del género Isurus (marrajo de
\end{abstract}

\section{Introduction}

The genus Isurus comprises two species: the shortfin mako Isurus oxyrinchus Rafinesque, 1809, reported world-wide in both temperate and tropical waters and the longfin mako Isurus paucus (Guitart Manday, 1966), whose distribution and habitat are poorly known. Isurus paucus has been considered an oceanic, tropical species, occurring in deep waters world-wide (Compagno et al. 2005). It displays aplacental viviparity with possible adelphophagy (Garrick 1967, Mollet et al. 2000). Size at birth ranges from 92 to $120 \mathrm{~cm}$ in total length (TL), with females reaching sexual maturity at $245 \mathrm{~cm}$ TL (Compagno 2001). This species has been reported as bycatch in tropical pelagic longline fisheries for tuna (Thunnus spp.), swordfish (Xiphias gladius), and other pelagic sharks belonging to the Lamnidae and Carcharhinidae families (Amorim et al. 1998, CastilloGéniz et al. 1998, Senba \& Nakano 2005, Marcano et al. 2005). Despite the apparently global distribution of this species, it has been poorly recorded (Compagno 2001, Compagno et al. 2005). The aim of this communication is to report the occurrence of Isurus paucus in the southeast Pacific, off the coast of Valparaíso, with a review of the morphological characteristics that allow distinguishing it from I. oxyrinchus. aleta corta), fueron la forma de la cabeza y hocico, la longitud de las aletas pectorales, la posición relativa de la primera aleta dorsal con respecto al margen posterior de las aletas pectorales y la posición relativa de la segunda aleta dorsal con respecto de la anal. Los antecedentes recopilados indican que la presencia de Isurus paucus no se restringiría a zonas de aguas cálidas, sino que también se distribuye en aguas templadas-frías.

Palabras clave: Isurus oxyrinchus, tiburón marrajo de aleta larga, Chile

\section{Material and methods}

Data reported here proceeded from a single specimen of shark captured by fishermen from Valparaíso (Portales fishing cave). A video of the captured animal (http:// www.revbiolmar.cl/Sharkvideo.flv) was recorded by a witness. Besides, graphic records obtained of the shark morphology were compared with photographs of the shortfin mako captured elsewhere. The poor quality of Fig. 1f was improved with Adobe ${ }^{\circledR}$ PhotoShop ${ }^{\circledR}$ software.

The longfin mako specimen was captured $20 \mathrm{~nm}$ from the coast off central Chile ( $32^{\circ} 30^{\prime} \mathrm{S}-74^{\circ} 30^{\prime} \mathrm{W}$ ) on March 27, 2007, by a pelagic longliner vessel targeting on shortfin mako. The individual was caught using baited hooks laid at depths between 0-20 m over an average water depth of $3000 \mathrm{~m}$. After landing, the mako was sold at the fish market and only the total length (TL) and total weight (TW) of the specimen were recorded. Sea surface temperature (SST) at capture site was estimated using data collected at night over a six-day period (March 2631, 2007), using the online PO.DAAC Ocean ESIP tool (POET-http://poet.jpl.nasa.gov). The main taxonomic characters utilized to distinguish at the species level the longfin mako from the shortfin mako were the shape of the head and snout; the length of the pectoral fins; the relative position of the first dorsal fin with respect to the 




Figure 1

Comparison of morphological features of Isurus oxyrinchus (Fig. 1a,b,c) and I. paucus (Fig. 1d,e,f). a and d, snout; b and e, pectoral fin and first dorsal fin; $c$ and $f$, second dorsal fin and anal fin

Comparación de caracteres morfológicos de Isurus oxyrinchus (Fig. 1a,b,c) e I. paucus (Fig. 1d,e,f). a y d, hocico; b y e, aleta pectoral y primera aleta dorsal; c y f, segunda aleta dorsal y aleta anal 
Table 1

Comparison of the external morphological diagnostic features of the genus Isurus (modified from Compagno et al. 2005, Ebert 2001). The number of the corresponding figure of the specimen is indicated, when available

Comparación de los caracteres morfológicos externos diagnósticos para el género Isurus (modificado de Compagno et al. 2005, Ebert 2001). Se indica el número de la figura correspondiente del ejemplar, en caso de estar disponible

\begin{tabular}{|c|c|c|}
\hline & Isurus oxyrinchus & Isurus paucus \\
\hline Snout & Snout acutely pointed (Fig. 1a). & Snout broadly pointed (Fig. 1d). \\
\hline Pectoral fins & $\begin{array}{l}\text { Pectoral fins semifalcate and with tips } \\
\text { relatively narrow, anterior margins } \\
\text { shorter than head length. }\end{array}$ & $\begin{array}{l}\text { Straight and very broad-tipped, anterior margins } \\
\text { equal to or longer than head length. }\end{array}$ \\
\hline First dorsal fin & $\begin{array}{l}\text { Origin over or just behind the pectoral } \\
\text { free rear tip; first dorsal-fin apex angular } \\
\text { and narrowly rounded; first dorsal-fin } \\
\text { height longer than base length (Fig. 1b). }\end{array}$ & $\begin{array}{l}\text { Origin well behind the pectoral free rear tip; first } \\
\text { dorsal-fin apex broadly rounded and hardly } \\
\text { angular; first dorsal-fin height longer than base } \\
\text { length (Fig. 1e). }\end{array}$ \\
\hline Teeth & $\begin{array}{l}\text { Lower anterior teeth strongly protruding } \\
\text { and horizontal on jaws even when mouth } \\
\text { is closed; anterior teeth with narrow, } \\
\text { more oblique cusps with flexed tips. }\end{array}$ & $\begin{array}{l}\text { Lower anterior teeth slightly protruding from } \\
\text { jaws and in line with the laterals; anterior teeth } \\
\text { with relatively broad, nearly straight cusps with } \\
\text { unflexed tips. }\end{array}$ \\
\hline Anal fin origin & $\begin{array}{l}\text { Slightly posterior to insertion of the } \\
\text { second dorsal fin (Fig. 1c). }\end{array}$ & Under midbase of second dorsal fin (Fig. 1f). \\
\hline Coloration & $\begin{array}{l}\text { Brilliant blue above, becoming a lighter } \\
\text { blue on its flanks (Fig. 1b). }\end{array}$ & Dark blue to black above (Fig. 1e). \\
\hline
\end{tabular}

posterior margin of the pectoral fins; the relative position of the second dorsal fin with respect to the anal fin.

\section{Results and discussion}

The captured specimen was a female identified as Isurus paucus. The shark measured $310 \mathrm{~cm}$ in total length and weighed $200 \mathrm{~kg}$. Stomach content was composed by squids, likely to be Dosidicus gigas, considering the simultaneous landings of this cephalopod and the shark in the fishing cave. A comparison of the external features between I. oxyrinchus and I. paucus are depicted in Table 1 and Fig. 1. The shape of the snout (Fig. 1a,d), the relative position of the first dorsal fin with respect to the posterior margin of the pectoral fins (Fig. 1b,e) and the insertion of the second dorsal fin with respect to the anal fin (Fig. 1c,f) were the most conspicuous morphological characteristics considered in the identification of the specimen. However, other taxonomic characteristics such as the shape of the pectoral fins and the degree of protrusion of the lower anterior teeth and body coloration could not be shown properly, due the lack of additional graphic material. On the other hand, teeth arrangement has been utilized as a diagnostic feature to differentiate within Isurus species. However, the available information indicates that in large size individuals, teeth become much alike in both species ${ }^{1}$.

The identification of this specimen from the southeast Pacific coast is interesting considering that worldwide records of $I$. paucus are scarce and often restricted to circumtropical waters (Compagno et al. 2005). The present record is complemented with the reports of Ebert (2001) and Queiroz et al. (2006), indicating an extension in the known latitudinal and bathymetric range of the species to more temperate and colder waters. The common assumption that I. paucus does not inhabit cold waters is no longer supported due to the evidence that longfin makos are able to regulate heat transfer with the environment, as well as other Lamnid species (Bernal et al. 2001, Goldman et al. 2004). The lack of capture records in the South Pacific Ocean could be a consequence of the capture processing system for pelagic sharks, which are often landed as headed, finned and gutted carcasses (Lamilla et al. 2005, 2008), which makes

${ }^{1}$ Bourdon J. 2005. Ontogenetic convergence? Questions in differentiating large mako sharks. http://www.elasmo.com/ selachin/slides/isurus_teeth/it_converge.htm. Visited on April 8, 2009. 
their identification difficult. Besides, I. paucus and $I$. oxyrinchus exhibit significant overlap in their distribution range, sharing similar ecological niches, fishing threats, and external morphological characteristics (Compagno 2001, Compagno et al. 2005). Sebastian et al. (2008) reported I. paucus by molecular DNA analysis of fins obtained from fin-storage warehouses in Chile that suggest unreported captures of this species. This background information suggests an extension of the known species range to more temperate waters, which until now was thought to be limited to tropical areas. Temperature range in the capture zone of the longfin mako female reported here differs greatly to that registered for its distribution, with a minimum of $23^{\circ} \mathrm{C}$ reported by Compagno (2001) compared with the $18.5^{\circ} \mathrm{C}$ in this report. On the other hand, it also points out the importance of investigating the specific composition of shark fishery captures in the southeast Pacific, to evaluate the conservation status of chondrichthyan species affected by regional fishing pressure.

\section{Acknowledgments}

This contribution was supported by Fondo de Investigación Pesquera (FIP) project $\mathrm{N}^{\circ} 2006-31$ and $\mathrm{N}^{\circ}$ 2008-60, Dirección de Investigación of Universidad Austral de Chile (DID-UACH) and Chile Shark Conservation Program (Programa de Conservación de Tiburones, PCT, Chile). We thank two anonymous referees for their valuable observations on an early version of this manuscript. To the fishermen G. Flores, $\mathrm{H}$. Flores and C. Oliva; and G. Ortiz and J. Betzhold for their valuable collaboration and provision of photographic material.

\section{Literature cited}

Amorim AF, CA Arfelli \& L Fagundes. 1998. Pelagic elasmobranchs caught by longliners off southern Brazil during 1974-97: an overview. Marine and Freshwater Research 49: 621-632.

Bernal D, C Sepulveda \& JB Graham. 2001. Water tunnel studies of heat balance in swimming mako sharks. Journal of Experimental Biology 204: 4043-4054.

Castillo-Géniz JL, JF Márquez-Farías, MC Rodríguez de la Cruz, E Cortés \& A Cid del Prado. 1998. The Mexican artisanal shark fishery in the Gulf of Mexico: towards a regulated fishery. Marine and Freshwater Research 49: 611620.
Compagno LJV. 2001. Sharks of the world. An annotated and illustrated catalogue of shark species known to date. 2 . Bullhead, mackerel and carpet sharks (Heterodontiformes, Lamniformes and Orectolobiformes). FAO Species Catalogue for Fishery Purposes 1(2): 1-269.

Compagno LJV, M Dando \& S Fowler. 2005. Sharks of the world, 368 pp. Princeton University Press, Princeton and Oxford.

Ebert DA. 2001. First eastern Pacific records of the longfin mako shark, Isurus paucus, Guitar-Manday, 1966. California Fish and Game 87: 117-121.

Garrick JAF. 1967. Revision of sharks of genus Isurus with description of a new species (Galeoidea, Lamnidae). Proceedings of the United States National Museum 118: 663-690.

Goldman KJ, SD Anderson, RJ Latour \& J Musick. 2004. Homeothermy in adult salmon sharks, Lamna ditropis. Environmental Biology of Fishes 71: 403-411.

Lamilla J \& C Bustamante. 2005. Guía para el reconocimiento de especies de: tiburones, rayas y quimeras. Oceana 17: 180.

Lamilla J, E Acuña, M Araya, M Oliva, I Kong, JC Villaroel, S Hernández, F Concha, R Vögler, C Bustamante \& E Mutschcke. 2005. Lineamientos básicos para desarrollar el Plan de Acción Nacional de Tiburones. Informe Final Proyecto FIP 2004-18: 2 Vol. [en línea]<http://www.fip.cl/ proyectos/2004/2004-18.htm>

Marcano LA, F Arocha, J Alío, J Marcano \& A Larez. 2005. Actividades desarrolladas en el programa de investigación intensiva sobre marlines en Venezuela, período 2003-2004. Collected Volume Scientific Papers International Commission for Conservation of Atlantic Tuna 58(5): 16031615.

Mollet HF, G Cliff, HL Pratt Jr \& JD Stevens. 2000. Reproductive biology of the female shortfin mako, Isurus oxyrinchus, with comments on the embryonic development of lamnoids. Fishery Bulletin 98: 299-318.

Queiroz N, S Araújo, P Ribeiro, P Tarroso, R Xavier \& AM Santos. 2006. A first record of longfin mako, Isurus paucus, in the mid-North Atlantic. JMBA2 - Biodiversity Records 5348: 1-2.

Sebastian H, PA Haye \& MS Shivji. 2008. Characterization of the pelagic shark-fin trade in north-central Chile by genetic identification and trader surveys. Journal of Fish Biology 73: 2293-2304.

Senba Y \& H Nakano. 2005. Summary of species composition and nominal CPUE of pelagic sharks based on observer data from the Japanese longline fishery in the Atlantic Ocean from 1995 to 2003. Collected Volume Scientific Papers International Comission for Conservation of Atlantic Tuna 58: 1106-1117. 